\title{
Economics of Adoption of Environmental Sustainable Fishing Techniques in Coastal Mangrove Niger Delta, Nigeria
}

\author{
N. C. Ehirim \\ Department of Agricultural Economic, \\ Federal University of Technology Owerri Imo State, Nigeria.
}

\section{N. C. Praise}

Department of Coperative Economics and Management, Institute of Management and Technology Enugu, Nigeria.

\author{
E. E. Osuji \\ Department of Agricultural Economic, \\ Michael Okpara University of Agriculture, Umudike, Abia State, Nigeria.
}

\author{
S. C. Onyemauwa \\ ${ }^{1}$ Department of Agricultural Economic, \\ Federal University of Technology Owerri Imo State, Nigeria.
}

\begin{abstract}
Reduction in social benefits in form of fishery stock depletion has some fishing techniques seriously fingered as low economic performance among fisher folks is leading to low revenue and unemployment in Mangrove Swamp Zone (MSZ) of Nigeria. Data were obtained from a two-stage sampling technique from 206 artisanal fishermen in two states within MSZ. Data on fisher folks' socioeconomic features, adoption level of environmental sustainable fishing techniques (ESFT), quantity and unit selling prices of species of catch as well as inputs were elicited using a well-structured questionnaire and analyzed using both descriptive and budgetary tools. Majority (68.9\% and $64.2 \%)$ of fishing activities are done with dugout canoes with only a few (16.0\% and $16.7 \%)$ motorized vessels that goes further off-shore in Bayelsa and Rivers State respectively. Adption level of ESFT of $\mathbf{2 6 . 1 \%}$ and $\mathbf{2 4 . 1 \%}$ for Bayelsa and River State respectively is low. Nematopalaemon hastatis recorded the highest $(46.6 \%)$ returns of USD 345.77 /fisherman, as fleet dominated sea-shore for it. Though artisanal fishing in MSZ seems economically sustainable with benefit-cost across different adopters greater than unity and rate of returns to investment ratio of 1.37 , ranging from 1.33 in Rivers to 1.44 in Bayelsa State, but poses a high marginal social cost to the breeding areas as catch is very concentrated at the sea shore of less than $5 \mathrm{~nm}$. There is a low catch of some pelagic species (Etamopterus penyl). The study recommends a persuasive extension demonstartion, litigation and the use water poilce to enforce strict adherence to principles ESFT for sustainable artisanal fishing activities in the mangrove region of Niger Delta.
\end{abstract}

Key Words: Environmental, Sustaianble, Artisanal Fisheries, Fishing Techniques, Mangrove

\section{INTRODUCTION}

An economic sustainable fishing practices must aim to save the natural stock, enhance biodiversity and ensure a steady returns without fishing beyond maximum sustainable yeild. Emperical studies have shown that continous catch that seems profitable to a large number of fishfolks, has become detrimental to the future welfare and environment of the fish folks. Mmom and Arokoyu (2010) observed that continous removal of fish from aquatic habitat is posing a threat to both the environment and the future welfare of fisherfolks in Mangroove 
Swamp Zones (MSZ). Eboh (1995) had already noted that the efforts of farmers towards increasing the output and achieving economic goals inadvertently distabilize environmental goals, hence obstructing the sustainable economic development. In the same way, fishfolks in the mangrove swamp zone who strive to increase catch per unit fishing effort are inadvertently fishing beyond maximum sustainable yield. Hardin (1968) called this situation 'tragedy of the common,' because the continous removal of fish from the aquatic environment in an area beyond socially efficient level will definitly decline the natural stock, thus the future benefits derivable from such resource in the area. Fishing requires the use of Environmental Sustainable Fishing Technique (ESFT). ESFT are technicalities designed to ensure that the natural fish stock are not destroyed while the fishfolks embarked on continous fishing expedition for their livelihood (Ita, 1992; Abiodun 1994 and NDDC, 2004).

Although the growing population and economic activities of Niger Delta Region (NDR) presupposed intensified oil exploration and industrialization, which no doubt deplete the ecosystem, excessive fishing with sophisticated and dangerous fishing techniques further complicate biodiversity depletion in the mangrove swamp (Bisong, 2001). Aquatic organisms may have modified features that enable them withstand the adverse effects of oil pollutions and industrial effluent in the zone (Adeyemo, 2003 and Olanike et. al., 2009), but identified malaise of environmental degredation due to excessive catch has been fingered to some endangered species and fishing beyond maximum sustainable yield (NDDC, 2004; Mmom and Arokoyu, 2010). Some fishing skills and techniques in the area may appear rewarding at first instant (because they increase catch), but they can distabilize the ecosystem, make aquatic organism go extinct and increase future returns impossible (Adedeji et. al., 2011).

Mangrove Swamp Zone (MSZ) is an ecological zone that streches between $5000-8580 \mathrm{~km}^{2}$ along Nigerian coastline with a spread of brackish water that is rich in alluvial deposites and natural fish stock (Mmom, 2007). The area is a suitable breeding ground for different species of fish (James, 2008 and James et. al., 2007) though it is saddled with rapid biodiversity depletion and annual decimation of aquatic population (David and Gianna, 2005; Mmom and Arokoyu, 2010). In view of the fact that indiscriminate use of traditional fishing input does not only distabilize the ecosystem but also reduced the future catch, Oko and Zelin (2010) and Naylor et.al. (2001) recommends that aquatic resources in the MSZ can be harness for economic growth if fishing technologies are ecologically friendly and efficiently managed. A policy that will not only put the use of obnoxious fishing inputs in check but facilitates a stable ecosystem and ensures a steady increase in returns in MSZ anchors this study. This study investigates the degree of adoption of ESFT and its effect on rate of returns to invetsment in artisanal fishing in MSZ of the Niger Delta Region of Nigeria.

\section{CONCEPTUAL FRAME WORK}

Sustainable fishery is usually compromised when fishersfolk struggle for improved livelihood. Destructive fishing practices are not part of sustainable fishery, hence management practices that allows more fleets in the water without monitoring whether clean fishing practices are performed by them is a gate way for environmental degredation. Incidental catch for instance removes juvinile fishes and the use of certain gear and vessel beyond certain areas and time as well as poison, dynamite and cyanide fishing are some of bad fishing practices that should be discouraged. Contrary to the earlier belive that ESFT will reduce catch, consequent to livelihood as fishersfolk fear being made job with these management techniques., Ehirim et. al. (2013) noted that a continous fishing with instante increase in catch without following the environmental regulations is devastating in the long-run. Hussen (2004) noted that the unit price of catch may rise above the equilibrim price while its catch level drops in the long run. 
The decline in output could lead to a reduction in Gross National Product (GNP) while factors of production falls due to the redution in output, hence increasing the level of unemployment in the sector.

Ita (992) and Abiodun (1994) differently acknowledged some techniques that can galvanize, a sustainable livelihood and a balanced aquatic ecosystem. Registration of vessels, gears and grew members and their licensing when theu meet some criteria, standard mesh size regulation, close are and season fishing and other clean fishing practices. Others are the use of a recommended mesh size for some dominant species in mangrove as well as the use of clap with gill nets in the flood plains, will ensure that only suitable table fishes are caught while the juvinile fishes are retained in water at all time. Again, catch-sort and drop otherwise called bycatch and discard method according to Eayrs (2005), creates a second chance for already trapped fish to grow to full maturity, produce more fishes before they are finally harvested. Adopting other techniques such as, water tenure system and Fishing beyond nautical miles, complying with close area and close season fishing practices, intensifying the use of flood plains by applying organic manure in the flood plains and around the continental shelves and encouraging aquaculture along artisanal fishing will reduce the pressure mounted on the natural stock by continous fishing. Also registration and licensing of the fishermen as well as keeping catch data, complying with gear regulation and quota restriction and prohibiting the use of poison and dynamites or explosives will not only check over-esploitation, but also ensure a healthy ecosystem, sustainable fishing and livelihood of the fish communities (Ita, 1992).

Strict enforcement of environmental regulation in artisanal fishing sector may reduce the marginal social cost and increase marginal social benefit but have a significant effect on the private cost of production, reduce output and increases unit price of catch of fish. However, the cost effect of enforcing environmental regulation on certain productive economic activities such as artisanal fisheries may be quite significant. Porter $(1990,1991)$ has hypothesized that strictly enforced environmental policy could have the effect of forcing firms to adopt more efficient production technologies that can reduce the production costs, increase returns and further stimulate economic growthin the long run. Resource use efficiency conciousness among artisanal fisher folks that strictly enforced environmental policies can stimulate multiplier effect on reduction in inflation and consumer price index, sustained output mximization, hence high gross national revenue and a reduction in employment

\section{MATERIALS AND METHOD}

The mangrove swamp zone (MSZ) is within the Niger Delta region of Nigeria. It consist the brackish water front of the coastal line of atlantic ocean. It is located within latitude $5^{0}$ and $7^{0} \mathrm{~N}$ and longitude $5^{0}$ to $8^{0} \mathrm{E}$ of Greenwich. It covers the state like Rivers, Delta, Bayelsa and AkwaIbom States of Nigeria. The area is a breeding site for different species of fish, accomodated the largest and highest number of fish settlements but the most distabilized ecosystem. A twoistage sampling technique was used in this study. First was a purposeful selection of two (2) stats: Bayelsa and Rivers State with predominant fishing settlements were selected out of the four states in the zone. The second stage was a purposive selection of the two largest fishing settlement in each of the states. Nembe and Brass watersides were selected from Bayelsa State while Kai and Oyorokoto-Opobo watersides in Rivers State were selected.

A random selection of artisanal fishermen from the list of fishermen per settlement kept with the Ministry of Agriculture and Natural Resources in each state. The list showed that Nember and Brass Water sides has 132 and 121 registered fishermmen respectively while Kai and Oyorokoto-Opobo waterside has 176 and and 184 fishermen respectively. A random selection 
of $80 \%$ of the fishermen from each of the list gave a total selection of 202 and 289 fishermen from Bayelsa and Rivers State respectively but only 106 and 120 responses were found useful for the study. A well structured questionaire was used to elicit information on socio-economic characteristics, adoption level of environmental sustainable fishing techniques, the quantity and prices of fishing inputs and output in the area between May and September 2010.

\section{ANALYTICAL METHOD AND MODEL SPECIFICATIONS}

Data were analzed using decriptive, inferential and econometric tools. Descriptive statistics was used to identify ESFT that were adopted. The ESFT identified in this study were those of Ita (1992) and Eayrs (2005) as shown in 3.1

$$
E S T=\left\{V_{i}: i, 1 \ldots 10\right\}
$$

Where

$V_{1}=$ The use of recommended mesh size for some species that is dominant in an area, $V_{2}=$ Catch-sort and Drop technique or By-catch and Discard Method (Eayrs, 2005). $V_{3}=$ Complying with Close Area and Close season fishing practice, $V_{4}=$ Intensifying the use of flood plains and the addition of organic manure in the flood plains and the continental shelves, $V_{5}=$ Use of clap nets and gill nets in the flood plains, $V_{6}=$ Encouraging aquaculture along artisanal fishing, $V_{7}=$ Adopting water tenure system and Maintaining about 5 or more nautical miles in fishing, $V_{8}=$ Registration and licensing of the fishermen as well as keeping catch data, $V_{9}=$ Complying with gear regulation and quota restriction, $V_{10}=$ Prohibition of the use of poison and dynamites or explosives. These were actually the techniques that can sustain the maximum sustainable yield (MYS) which the fish community is expected to adhere to strictly (Ita, 1992).

Ozor and Madukwe (2001) noted that adoption process follows a seven-point likert type of scale (called NAEITA + D), with asigned ordinal values of between 0 and 6 (Lionberger, 1960 and Cameron, 1999). Therefore, adoption score of a fisherman for each ESFT his maximum stage in adoption process.

The mean and standard mid value as shown in 3.2 and 3.3 respectively were compared to select the adopted ESFT. An ESFT is adopted when $M \geq$ a standard mid value of 3.0

$$
\begin{gathered}
\bar{M}=\frac{\sum_{i=1}^{7} F X}{\sum F} \text { where } 0 \leq \bar{M} \leq 6---------------------3.1 \\
G M A=\frac{\sum_{j=1}^{10} \bar{M}}{10}--------------------------3.2
\end{gathered}
$$

Where $i=1,2 \ldots 7$ and $j=1,2,3 \ldots 10$

$$
S M V=\frac{0+1+2+3+4+5+6}{7}=3.0----------------3.3
$$

Where;

$\bar{M}=$ Mean Adoption of an ESFT

GMA $=$ Grandmean adoption 
$\mathrm{X}_{\mathrm{ij}}=$ Adoption stage in the adoption process of an ith farmer in jth technique obtained from ordinal values attached to the adoption process.

$\mathrm{F}=$ Frequency of Fishermen within the same adoption stage in a particular technology.

SMV = Standard mid value

Fishermen were further differentiated to various adopters category based on their adoption potential. Adoption potential is the possible degree of adoption level an ith fisherman in all the available ESFT as at the period of this study. This is expressed as the mean adoption level in all ESFT. A fisherman is at the highest adoption potential if he shows aggresive tendencies in adopting all the ESFT with the shortest period of time but becomes the least if otherwise. The categorization is done thus

$$
A P=\frac{{ }_{i=1}^{N} A D L_{i}}{N} \pm \operatorname{Std} \cdot \operatorname{Dev}(n)
$$

Where;

AP = Adoption Potential of an ith fisherman

$\mathrm{ADL}=$ Adoption Level of an ith fisherman in all the ESFT

$\mathrm{N}=$ Total number of ESFT introduced and used by at least a fisherman the area.

Std. $\operatorname{Dev}(\mathrm{n})=$ The standard deviation of the mean adoption level, and $\mathrm{n}$ is the successive category level.

Adoption potential is highly influenced by extension effectiveness, technology practicability and compaticability, cost and most importantly time.

The economic sustainability of artisanal fishing in the area based on states in mangrove swamp zone and adopters categories were obtained using a budgetary analysis such as gross margin analysis and rate of returns to investment. The gros margin and rate of truturns model are expressed as;

$$
\begin{array}{r}
\text { Gross Margin }={ }^{n} Y P_{y}{ }_{i=1}^{n} P_{X} X_{1}+\ldots+P_{x} X_{i} \\
R T I_{i}=100 \frac{{ }^{n} Y P_{y}{ }^{n}{ }_{i=1}^{n} P_{X 1} X_{1}+\ldots+P_{x} X_{i}+K}{{ }^{n} P_{X 1} X_{1 j}+\ldots+P_{x n} X_{i j}}
\end{array}
$$

$0 R T I_{i} \quad 1$ when the enterprise is economically sustainable

Where;

$R T I$ is already defined,

$\mathrm{Y}_{\mathrm{i}}$ is the quantity of catch of an ith fisherman,

$\mathrm{P}_{\mathrm{yi}}$ is the unit price of catch,

$\mathrm{P}_{\mathrm{xi}}$ is the unit input price of an ith input used

$\mathrm{X}_{\mathrm{ij}}$ is the quantity of $\mathrm{jth}$ input used by an ith fisherman.

$\mathrm{K}$ is the fixed inputs such as depreciation

$$
\text { Benefit } / \text { Cost ratio }=\frac{D_{\text {Benefit } @ 19 \%}}{D_{\text {Cost } @ 19 \%}}
$$




\section{Where;}

$D_{\text {benefit } @ 19}=$ Discounted Benefit at 19\% discount factor

$\mathrm{D}_{\text {cost } 19 \%}=$ Discounted cost at $19 \%$ dicount factor

When the ratios is equal to 1 , then the returns can comfortably take care of the investment even in the long run, but if it is less than 1 , then the enterprise ie espected to continue to operate in the very short run as it can meet its immediate financial obligations while economic sustainability is expected to take place in the long run. When the ratio is less than zero (0), the enterprise fails to be economically sustainable both in the short and the log run. The fisherman closes down at this stage.

\section{RESULTS AND DISCUSSIONS \\ Discriptive Statistics of Artisanal Fish folks in Mangrove Swamp Zone of Niger Delta, Nigeria}

Table 1 presents the socio-economic distribution of the fishermen in the mangrove zone of Niger Delta Region of Nigeria. The result shows that there are more male fishermen in the area with $86.8 \%$ and $83.3 \%$ fof them from Bayelsa and River State respectively. Their mean age is 39.9 and 33.3 years for Bayelsa and Rivers State respectively with majority (33.9\%) of them in Bayelsa between 31 to 40 years $33.3 \%$ of them between 21 to 30 years of age in River State. Few of them (17.0\%) are older than 60 years of age in Bayelsa and River State. Again, few $(15 \%$ and $8.3 \%)$ of them have relatively higher fishing experience of above 20 years, implying that artisanal fisheries is centered more around the young age category than the old people. The level of formal education among the fishfolk is high with $44.3 \%$ and $38.3 \%$ of them in Bayelsa and River State having up to secondary education. Extension contact is as low as 6 times per fishing season just as they try to keep a relatively small hosuehold size of less than 5 persons perhousehold. 
Table 1. Scocio-Economic Characteristic of the Fishermen

\begin{tabular}{|c|c|c|c|c|}
\hline \multirow[t]{2}{*}{ Variable } & \multicolumn{2}{|c|}{ Bayelsa State } & \multicolumn{2}{|c|}{ Rivers State } \\
\hline & Frequency & Relative (\%) & Frequency & Relative (\%) \\
\hline \multicolumn{5}{|l|}{ Age (Years) } \\
\hline 20 or less & 2 & 1.9 & 19 & 15.8 \\
\hline $21-30$ & 21 & 19.8 & 40 & 33.3 \\
\hline $31-40$ & 36 & 33.9 & 21 & 17.5 \\
\hline $41-50$ & 29 & 27.4 & 20 & 16.7 \\
\hline $51-60$ & 10 & 9.4 & 15 & 12.5 \\
\hline $61-70$ & 6 & 5.7 & 4 & 3.3 \\
\hline More than 70 Years & 2 & 1.9 & 1 & 0.8 \\
\hline Total & 106 & 100.0 & 120 & 100.0 \\
\hline Mean & 39.9 & - & 35.2 & - \\
\hline \multicolumn{5}{|c|}{ Level of Formal Education } \\
\hline No Formal Education & 20 & 18.9 & 36 & 30.0 \\
\hline Adult Education & 11 & 10.3 & 10 & 8.3 \\
\hline Primary Education & 21 & 19.8 & 23 & 19.2 \\
\hline Secondary Education & 47 & 44.3 & 46 & 38.3 \\
\hline Tertiary Education & 7 & 6.6 & 5 & 4.2 \\
\hline Total & 106 & 100.0 & 120 & 100.0 \\
\hline Mean & 7.9 & - & 6.6 & - \\
\hline \multicolumn{5}{|c|}{ Years of Fishing Experience } \\
\hline $1-10$ & 65 & 61.3 & 65 & 54.2 \\
\hline $11-20$ & 25 & 23.6 & 45 & 37.5 \\
\hline $21-30$ & 7 & 6.6 & 5 & 4.2 \\
\hline $31-40$ & 8 & 7.5 & 2 & 1.6 \\
\hline Above 40 Years & 1 & 0.9 & 3 & 2.5 \\
\hline Total & 106 & 100.0 & 120 & 100.0 \\
\hline Mean` & 13.1 & - & 11.3 & - \\
\hline \multicolumn{5}{|c|}{ Extension Contacts Made } \\
\hline No Extension Contact & 49 & 46.2 & 38 & 31.6 \\
\hline $1-5$ & 21 & 19.8 & 32 & 26.7 \\
\hline $6-10$ & 17 & 16.0 & 31 & 25.8 \\
\hline $11-15$ & 14 & 13.2 & 15 & 12.5 \\
\hline More than 15 & 5 & 4.7 & 4 & 3.3 \\
\hline Total & 106 & 100.0 & 120 & 100.0 \\
\hline Mean & 4.9 & - & 5.4 & - \\
\hline \multicolumn{5}{|l|}{ Household Size } \\
\hline $1-5$ & 78 & 73.6 & 81 & 67.5 \\
\hline $6-10$ & 21 & 19.8 & 26 & 21.7 \\
\hline 11 or More & 7 & 6.6 & 13 & 10.0 \\
\hline Total & 106 & 100.0 & 120 & 100.0 \\
\hline Mean & 5 & - & 5 & - \\
\hline \multicolumn{5}{|l|}{ Gender } \\
\hline Male & 92 & 86.8 & 100 & 83.3 \\
\hline Female & 14 & 13.2 & 20 & 16.7 \\
\hline Total & 106 & 100.0 & 120 & 100.0 \\
\hline \multicolumn{5}{|l|}{ Marital Status } \\
\hline Single & 27 & 25.5 & 53 & 44.2 \\
\hline Married & 78 & 73.6 & 66 & 55.0 \\
\hline Divorce/Separated & 1 & 0.4 & 1 & 0.8 \\
\hline Total & 106 & 100.0 & 120 & 100.0 \\
\hline
\end{tabular}

Source: Field Survey 2011

Source Field Survey 2013

Fishing Assets and Fishing Activities in Mangrove Swamp Zone of Niger Delta Nigeria

Table 2 below shows the distribution of fishermen based on their level of fishing assets and fishing activities in the mangrove areas. The result showed that there is an open access to fishing in the area with majority of the respondents engaging in only artisanal fishing as source 
of livelihood. Mean fishing distance off-shore is lower than 5 nautical miles (nm). About 83.0\% of them in Bayelsa and over 91.6\% of them in Rivers state are fishing in less than 5 nautical miles (nm) off-shore. Such fishing distance has a devastating effect on the growth of juvinile fishes and fish breeding inthe mangrove. Few fishermen of less than $17.3 \%$ in Bayelsa and $8.4 \%$ in Rivers State were actually complying with the regulations of fishing beyond $5 \mathrm{~nm}$ offshore. Since fishing is a common means of livelihood, it means that the natural stock is at risk as the breeding areas within the mangrove will be quickly and easily destroyed with excessive fishing activities by fishfolks. The use of cast nets is common (45.2\%) in Bayelsa and long lines and hook is the commonest (45.8\%) in Rivers State. The use of dugout that do not move far into the mid ocean is common in both states with $68.9 \%$ and $64.2 \%$ of fisher folk in Bayelsa and Rivers state using such vessel for fishing around the mangrove swamp zone. The large concentration of this type of vessel on the breeding area may not be socially desirable since it inceases the marginal social cost. The result showed a few used mortorized vessel by the fishers folk with only $16.0 \%$ and $16.7 \%$ of fishermen in Bayelsa and Rivers state using such vessels for fishing. This implies that the fisher folk may not have enough capital to acquire this motorized fishing vessel that can facilitate off-shore fishing expedition to the mid ocean for pelagic fishes. 
Table 2. Distribution of Fishermen by their Assets and Fishing Activities

\begin{tabular}{|c|c|c|c|c|}
\hline \multirow[t]{2}{*}{ Variable } & \multicolumn{2}{|c|}{ Bayelsa State } & \multicolumn{2}{|c|}{$\underline{\text { Rivers State }}$} \\
\hline & Freq & $\%$ & Freq & $\%$ \\
\hline \multicolumn{5}{|l|}{ Fishing Distance } \\
\hline Less than 1 Nautical mile & 52 & 49.0 & 62 & 51.6 \\
\hline $1-5$ & 36 & 34.0 & 48 & 40.0 \\
\hline $6-10$ & 12 & 11.3 & 8 & 6.7 \\
\hline Greater than 10 Nautical miles & 6 & 5.7 & 2 & 1.7 \\
\hline Total & 106 & 100.0 & 120 & 100.0 \\
\hline Mean Distance covered & 2.9 & & 2.2 & \\
\hline \multicolumn{5}{|l|}{ Fishing Gears } \\
\hline Long lines/Hooks & 47 & 44.3 & 55 & 45.8 \\
\hline Cast Netting & 48 & 45.2 & 32 & 26.7 \\
\hline Drift Netting & 17 & 16.0 & 28 & 23.3 \\
\hline Trapping & 12 & 11.3 & 13 & 10.8 \\
\hline Others & 4 & 3.8 & 3 & 2.5 \\
\hline Total & $128^{+}$ & - & $131^{+}$ & - \\
\hline \multicolumn{5}{|l|}{ Fishing Vessel } \\
\hline Dugout Canoes & 73 & 68.9 & 77 & 64.2 \\
\hline Plank Canoes & 41 & 36.6 & 32 & 26.7 \\
\hline Motorized Canoes & 17 & 16.0 & 20 & 16.7 \\
\hline Total & $131^{+}$ & - & $129^{+}$ & - \\
\hline \multicolumn{5}{|l|}{ Access to Water } \\
\hline Open Access & 89 & 84.0 & 117 & 97.5 \\
\hline Closed Access & 17 & 16.0 & 3 & 2.5 \\
\hline Total & 106 & 100.0 & 120 & 100.0 \\
\hline \multicolumn{5}{|l|}{ Occupation } \\
\hline Fishing Only & 86 & 81.1 & 75 & 62.5 \\
\hline Fishing and Farming Only & 1 & 0.9 & 13 & 10.8 \\
\hline Fishing and Trading Only & 2 & 1.9 & 7 & 5.8 \\
\hline Fishing and Schooling Only & 9 & 8.5 & 15 & 12.5 \\
\hline Fishing and Civil Service & 8 & 7.5 & 2 & 1.7 \\
\hline Fishing and Craft & 0 & 0 & 8 & 6.7 \\
\hline Total & 106 & 100.0 & 120 & 100.0 \\
\hline \multicolumn{5}{|l|}{ Technology Compatibility and } \\
\hline Practicability & 46 & 43.4 & 61 & 50.8 \\
\hline Yes & 32 & 30.2 & 16 & 13.4 \\
\hline No & 28 & 26.4 & 43 & 35.8 \\
\hline Indifference & 106 & 100.0 & 120 & 100.0 \\
\hline Total & & & & \\
\hline
\end{tabular}

\section{Source: Field Survey 2013}

\section{The level of Adoption of Environmental Suatianble Fishing Technologies in Mangrove Zone}

Table 3b. presents the mean adoption levels of Environmental sustainbale fishing techniques (ESFT) in Mangrove Swamp zone of Niger Delta, Nigeria. ESFT were not massively adopted in the mangrove swamp zone of Nigeria given the low grand mean adoption score of 1.82 and 1.69 in Bayelsa and Rivers State respectively. There is a total adoption level of $26.1 \%$ and $24.1 \%$ of the total adoption in Bayelsa and River State, implying that about $73.9 \%$ and $75.9 \%$ of ESFTs have not been adopted in Bayelsa and Rivers States respectively. Judging from the mean adoption of the 10 included technologies, the mean scores are less than the standard mid value of 3.0 except the close area and season technology and avoidance of dynamites and explosions with mean adoption score of 3.21 and 3.27 respectively in Bayelsa State. It therefore implies that the two ESFT were the only technologies adopted by fishermen in Bayelsa. In the same way, avoidance of dynamites with a mean adoption score of 3.56 which is greater than 3.0 was the only ESFT adopted in River State. Though other ESFT in the two states were at various level of adoption score, there is no strong evidence that they are capable of keeping breeding areas 
sustainable. This finding suggests that environmental regulations in artisanal fisheries are highly violated in the mangrove areas, hence a possible increase in marginal social cost associated with artisnal fisheries in the area.Ehirim et. al. (2013) opined that the poor rate of adoption may be due to declined extension effectiveness in the use of sustainable environmental fishing technologies for their fishing activities in the area

It could be the recent strict enforcement of the policy on close area and close season fishing as well as the use of dynamite in the mangrove by the state house assembly that enhanced the adoption of these practices in artisanal fisheries. It is advised by this study that a strict enforcement of the other environmental regulations in captured fisheries be made by the legislatures to facilitate not only a sustainable livelihood for fisher folks but reduces the marginal social cost and enhance the marginal social benefit of the fishing communities around the mangrove area. This study also suggestes a effective extension education approach that can lead to a change in fishing behaviour by persuading the use of ESFT by fisher folk so as to save the areas from total environmental distruction.

\section{Adopters Category of ESFT by Fishermen in MSZ of Nigeria}

The result in Table 3a. reveals the level of different adopters of environmentalsustainable fishing techniques in MSZ. It could be seen from the rsult that majority ( $41.5 \%$ and $36.7 \%$ ) of fishermen in Bayelsa and Rivers State are within late adopters category respectively while $28.3 \%$ and $25.0 \%$ are laggards in Bayelsa and Rivers State respectively. Few $(15.1 \%$ and $10.0 \%$ ) of the fishermen is aggregate of innovator and early majority inBayelsa and Rivers State respectively. This finding eveals that majority ofthese fishermen are laggards and late adopters hence, adoption of environmental sustainable fishing techniques must be more pragmatic to enable the never adopters move into the early majority category with time.

Table 3a. Adoption Score/Intensity and Adopters Categories of Sustainable Fishing Practices in the Niger Delta of Nigeria

\begin{tabular}{|l|c|c|c|c|c|}
\hline \multicolumn{1}{|c|}{ States } & \multicolumn{2}{c|}{ Bayelsa } & \multicolumn{2}{c|}{ Rivers State } \\
\hline Adopters Category & $\begin{array}{c}\text { Adoption } \\
\text { Intensity } \\
\text { Class Limits }\end{array}$ & Frequency & \% & Frequency & $\%$ \\
\hline Laggards/Never Adopters & $0-8.0$ & 30 & 28.3 & 30 & 25.0 \\
\hline Late Majority & $8.5-19.0$ & $\varkappa 44$ & 41.5 & 44 & 36.7 \\
\hline Late Majorities & $19.5-30.0$ & 16 & 15.1 & 34 & 28.3 \\
\hline Early Adopters & $30.5-41.0$ & 14 & 13.2 & 10 & 8.3 \\
\hline Innovators & $41.5-60.0$ & 2 & 1.9 & 2 & 1.7 \\
\hline Total & - & 106 & 100.0 & 120 & 100.0 \\
\hline Mean & - & 16.5 & & 18.8 & \\
\hline Adoption Potential & \multicolumn{2}{|c|}{$-19.0+11 \mathrm{n}$} \\
\hline
\end{tabular}

Source Field survey $2013(n=0,1,2 \ldots N$ represents the level of Adoption intensities) 
Table 3b. Mean Adoption and Adopted Technology in Mangrove Swamp Region of Nigeria.

\begin{tabular}{|c|c|c|c|c|c|}
\hline \multirow{2}{*}{\multicolumn{2}{|c|}{$\begin{array}{c}\text { States in Mangrove Zone } \\
\begin{array}{c}\text { Environmental Sustainable Fishing } \\
\text { Techniques }\end{array} \\
\end{array}$}} & \multicolumn{2}{|c|}{ Bayelsa State $(n=106)$} & \multicolumn{2}{|c|}{ Rivers State $(n=120)$} \\
\hline & & $\overline{\boldsymbol{X}}$ & Remark & $\overline{\boldsymbol{X}}$ & Remark \\
\hline 1 & Recommended Mesh Size & 1.51 & $\mathrm{Na}$ & 2.75 & $\mathrm{Na}$ \\
\hline 2 & Catch sort and Drop Method & 0.72 & $\mathrm{Na}$ & 0.69 & $\mathrm{Na}$ \\
\hline 3 & Close Area and Season Fishing & 3.21 & $\mathrm{Ad}$ & 1.02 & $\mathrm{Na}$ \\
\hline 4 & Use of Flood Plains & 1.26 & $\mathrm{Na}$ & 0.78 & $\mathrm{Na}$ \\
\hline 5 & $\begin{array}{l}\text { Use of Gilll and Clap net in the Flood } \\
\text { Plains }\end{array}$ & 1.66 & $\mathrm{Na}$ & 0.70 & $\mathrm{Na}$ \\
\hline 6 & Practicing Agriculture & 1.41 & $\mathrm{Na}$ & 1.57 & $\mathrm{Na}$ \\
\hline 7 & Practicing Water Tenure & 1.31 & $\mathrm{Na}$ & 1.28 & $\mathrm{Na}$ \\
\hline 8 & Registration/ License & 1.85 & $\mathrm{Na}$ & 2.38 & $\mathrm{Na}$ \\
\hline 9 & Quota Restriction & 2.08 & $\mathrm{Na}$ & 2.15 & $\mathrm{Na}$ \\
\hline 10 & Avoiding Dynamited Poison & 3.27 & $\mathrm{Ad}$ & 3.56 & $\mathrm{Ad}$ \\
\hline \multicolumn{2}{|c|}{$\begin{array}{l}\text { Grand Mean Adoption } \\
\text { Percentage Adoption }\end{array}$} & \multicolumn{2}{|c|}{$\begin{array}{c}1.82 \\
26.1 \%\end{array}$} & \multicolumn{2}{|c|}{$\begin{array}{c}1.69 \\
24.1 \%\end{array}$} \\
\hline
\end{tabular}

Source: Field Survey 2013

\section{Economic Suatianability by States in the Mangrove Swamp Zone of Niger Delta Nigeria}

Table 4 presents the cost and returns of artisanal fishing activities across the states in the mangrove swamp zone in the Niger Delta region of Nigeria. The result reveals that shrimps Nematopalaemon hastatis caught in artisanal fisheries in MSZ generated about USD 345.77 /fisherman or $46.6 \%$ of a fisherman's total returns. This is followed by the catch of shark Etamopterus penyi with USD 250.04 /fisherman or $33.7 \%$ of his total returns. A critical look across the states studied shows that about USD $320.07 /$ fisherman and USD 232.48 /fisherman or $48.8 \%$ and $34.93 \%$ of the returns from the catch in Bayelsa are made from shrimps and sardines respectively. In the same way, about USD 345.77/fisherman and USD 250.04 or $46.6 \%$ and $33.7 \%$ of the total returns are made from shrimps and shark respectively in Rivers state. The high contirbutions of shrimps and sardine to the total revenue of the fishermen in MSZ could be the reason for large the concentration of fishing activities within swamp zones than farther off shore.

The implication of this finding to the MSZ ecosystem is the fast and continous loss of some endengered species of fish. Apart from being suitable breeding, World Bank (1995) and NDDC (2004) have observed that fishing close to the sea shore or the MSZ will lead to the collapse of targeted fish species like Sardines Sardinella maderenis and other species. Hence, the social benefit drawn from this excessive shorelne fishing will drop drastically in the long run with an attendant high marginal social cost. Fisher folks have little or no fishing effort on the catch of pelagic fishes and other highly valued species such as suitable table sized sharks farther offshore. There is a significant implication of this to MSZ. Just as the diturbances caused as a result of concentrated fishing in MSZ or ocean shoreline can reduce the breeding performance of fishes, extinction of endergered species from the mangrove swamp is eminent with a high external cost, which may not be socially desirable for the economy (Hussen. 2004). The consequencies may include reduction in gross national product due to low output, high unemployment resulting from the reduction in use of factors of production and high unit cost of fishes leading to inflation in the economy.

The result further shows that depreciation of fixed inputs, labour cost, lubricants and fuel constiitute the highest cost of artisanal fisheries in area while charges on gross vessel lenght and penalty on abuse of water resources are the least. This suggest that artisanal fishing in the area is gradually experiencing a very high private cost per unit catch without a reduction in maginal social cost. A higher charge and strict penalty could caution the bad use of water 
resources and reduce the marginal cost in the area but apparently, the open access to water and lack of strict litigation policies in the area may be the reason for such serious abuse of water use. This is threatening the natural stock. It could be deduced from the finding that since fish folks can escape the cosequencies of the abuse to water use, less attension will be paid to ESFT in the area.

The gross margin for artisanal fisheries in MSZ of Niger Delta region is USD513.50 per fisherman, which is about $69.2 \%$ of the total cost of catch. The value ranges from USD557.54 or $68.2 \%$ of the total cost of catch in River state to USD488.88 per fishermen or $73.3 \%$ of the total cost of catch in Bayelsa. It could be deduced from the result that the rate of return to investment in artisanal fisheries in MSZ is 36.7\% with Bayelsa and Rivers state having 41.1\% and $33.1 \%$ respectively. Artisanal fisheries in Mangrove area of Niger Delta region is economically sustainable despite the low adoption of environmental sustainable fishing techniques in the area. An increase in total cost of catch by $100 \%$ will give a more than $41.1 \%$ increase in return in the Bayelsa State, 33.1\% increase in returns in Rivers State and about $36.7 \%$ increase in returns for all the fish folk in the Mangrove swamp zone of Niger Delta region of Nigeria. A benefiit-cost ratio of 1.37 from the pooled result is an indication that the enterprise is viable now but the viability in future is questionable giving the rate of removal of juvinile fishes from the swamp.

\section{Economic Suatianability by Adopters of ESFT in the Mangrove Swamp Zone, Niger Delta, Nigeria.}

Table 5. presents the cost and returns of artisanal fishery activities of different adopters of environmental sustainable fishing techniques in MSZ of Niger Delta, Nigeria. The benefit-cost ration that is greater than unity for different adopters showed that enterprise is economically sustianable the different adopters. However, there is an interesting finding from this study. Some species like shark Etamopterus penyl that are mostly found off-shore contributed more to revenue of adopters of ESFT than others. The Principle of ESFT belived that fishing farther off shore will help sustain the breeding areas provided by the MSZ and adopters of ESFT are abided by this particular principle (Naylor et.al., 2001 and Oko and Zelin, 2010). It could be revealed from this result that about USD 332.08/innovator or 39.1\% of his total returns, USD 332.58 /early majority adopter or $40.9 \%$ of his total returns and USD 312.58/late majority adopter or $39.7 \%$ of his total returns is relatively higher than only USD 124.78 per late adopter or $20.7 \%$ of his returns and USD 158.18 per laggard or $23.2 \%$ of his total return. This provides a strong evidence that despite the difficulties associated with adoption of ESFT, the techniques may accomodate more returns afterall. The innovators, early majority and late majoritty fishermen are taking advantage of species farther off-shore to generate more revenue than the late adopters and the laggards in MSZ. This is due to their adehrance to the principles of ESFT than the restofthe adopters in the area.

The study therefore suggeste that although shrimps and sardine that are close to sea shores contributed more to their revenue of individual adopters, it is important to remove the mind of these group of fishermen from existing trend of fishing close to the sea-shore so as to achieve a stable ecosystem in the MSZ. This can be achieved through a persuasive extension education and good artisanal fishing demonstration that must abide stricktly with the principles of ESFT by model agents or extension agents. 
Table 4. Budgetary Analysis According the States in Mangrove Swamp Zone, Niger Delta Region,

\begin{tabular}{|c|c|c|c|c|c|c|c|}
\hline \multicolumn{8}{|c|}{ Nigeria } \\
\hline \multirow{2}{*}{$\begin{array}{l}\text { States } \\
\text { Items }\end{array}$} & \multicolumn{3}{|c|}{ Bayelsa State $(n=106)$} & \multicolumn{2}{|c|}{ Rivers State $(n=120)$} & \multicolumn{2}{|c|}{ Pooled $(n=206)$} \\
\hline & Unit & $\begin{array}{c}\text { USD/Fisherma } \\
\text { n }\end{array}$ & (\%) & $\begin{array}{c}\text { USD/Fisherma } \\
\text { n }\end{array}$ & $(\%)$ & $\begin{array}{c}\text { USD/Fisherma } \\
\text { n }\end{array}$ & (\%) \\
\hline $\begin{array}{l}\text { Revenue } \\
\text { Sardines: } \\
\text { Sardinella } \\
\text { maderenis }\end{array}$ & USD & 232.48 & 34.9 & 216.69 & 26.5 & 224.59 & 30.3 \\
\hline $\begin{array}{l}\text { Brackish: Catfish } \\
\text { Chrysichthys } \\
\text { nigrodigitatus }\end{array}$ & & 208.38 & 31.3 & 179.78 & 22.0 & 194.08 & 26.2 \\
\hline $\begin{array}{l}\text { Sharks: } \\
\text { Etamopterus } \\
\text { penyi }\end{array}$ & & 180.00 & 27.0 & 320.07 & 39.2 & 250.04 & 33.7 \\
\hline $\begin{array}{c}\text { Shrimps: } \\
\text { Nematopalaemon } \\
\text { hastatis }\end{array}$ & & 320.07 & 48.0 & 371.47 & 45.4 & 345.77 & 46.6 \\
\hline $\begin{array}{c}\text { (A) Total } \\
\text { Revenu } \\
\text { e }\end{array}$ & & 940.93 & & 1088.01 & & 1014.47 & \\
\hline$\frac{\text { Variable Cost }}{\underline{\text { Items }}}$ & & & & & & & \\
\hline Labour (manday) & Mandays & 184.45 & 27.7 & 209.80 & 25.7 & 197.13 & 26.5 \\
\hline $\begin{array}{c}\text { Bait } \\
\text { (Kilogramme) }\end{array}$ & $\underset{\mathrm{e}}{\text { Kilogramm }}$ & 24.83 & 3.7 & 27.00 & 3.3 & 25.92 & 3.5 \\
\hline Fuel (liters) & Litres & 110.07 & 16.5 & 135.34 & 16.6 & 122.71 & 16.5 \\
\hline $\begin{array}{l}\text { Lubricants } \\
\text { (liters) }\end{array}$ & $"$ & 118.01 & 17.7 & 142.42 & 17.4 & 130.21 & 17.5 \\
\hline $\begin{array}{l}\text { Charge on Gross } \\
\text { Vessel Length }\end{array}$ & $\begin{array}{c}\text { USD } \\
,\end{array}$ & 8.92 & 1.3 & 21.56 & 2.6 & 15.24 & 2.1 \\
\hline $\begin{array}{l}\text { Water Penalty } \\
\text { (B) Total } \\
\text { Variable Cost }\end{array}$ & $"$ & $\begin{array}{c}5.76 \\
\mathbf{4 5 2 . 0 5}\end{array}$ & $\begin{array}{c}0.8 \\
67.8\end{array}$ & $\begin{array}{c}13.75 \\
\mathbf{5 4 9 . 8 7}\end{array}$ & $\begin{array}{c}1.7 \\
67.3\end{array}$ & $\begin{array}{c}9.75 \\
\mathbf{5 0 0 . 9 6}\end{array}$ & $\begin{array}{c}1.3 \\
\mathbf{6 7 . 5}\end{array}$ \\
\hline$\frac{\text { Fixed Cost }}{\text { Items }}$ & $\begin{array}{c}\text { USD } \\
"\end{array}$ & & & & & & \\
\hline Depreciation & & 155.64 & 23.3 & 167.16 & 20.4 & 161.40 & 21.7 \\
\hline $\begin{array}{l}\text { Registration and } \\
\text { Training }\end{array}$ & $"$ & 45.55 & 6.8 & 79.79 & 9.8 & 62.67 & 8.4 \\
\hline Dues & & 13.41 & 2.0 & 20.75 & 2.5 & 17.08 & 2.3 \\
\hline $\begin{array}{c}\text { (C) Total Fixed } \\
\text { Cost }\end{array}$ & & 214.60 & 32.2 & 267.71 & 32.7 & 241.15 & 32.5 \\
\hline $\begin{array}{l}\text { (D) Total Cost } \\
(\mathrm{B}+\mathrm{C})\end{array}$ & & 666.65 & $\begin{array}{c}100 . \\
0\end{array}$ & 817.58 & $\begin{array}{c}100 . \\
0\end{array}$ & 742.11 & $\begin{array}{c}100 . \\
0\end{array}$ \\
\hline $\begin{array}{c}\text { (E) Gross } \\
\text { Margin }\{A-B\}\end{array}$ & & 488.88 & 73.3 & 557.54 & 68.2 & $\mathbf{5 1 3 . 5 0}$ & 69.2 \\
\hline $\begin{array}{l}\text { (F) Net Income } \\
\text { (NI) }\{\mathrm{A}-(\mathrm{B}+\mathrm{C})\}\end{array}$ & & 274.28 & 41.1 & 270.43 & 33.1 & 272.35 & 36.7 \\
\hline $\begin{array}{c}\text { (G) RTI } \\
\{100(\text { F } / C)\}\end{array}$ & Percentage & 41.1 & & 33.1 & & 36.7 & \\
\hline $\begin{array}{l}\text { (F) Benefit/Cost } \\
\text { Ratio (@ 0.19) }\end{array}$ & Ratio & 1.41 & & 1.33 & & 1.37 & \\
\hline
\end{tabular}

\section{Source: Field Survey 2013}


Table 5. Budgetary Analysis Based on Adoption Categories of ESFT in Mangrove Swamp Zone of Niger Delta Region of Nigeria

\begin{tabular}{|c|c|c|c|c|c|c|c|c|c|c|c|c|}
\hline $\begin{array}{l}\text { Adopters } \\
\text { Categories } \\
\text { nount Per } \\
\text { sherman }\end{array}$ & $\begin{array}{r}\text { Innov } \\
\text { Amo }\end{array}$ & tors & \multicolumn{2}{|c|}{$\begin{array}{c}\text { Early } \\
\text { Majority } \\
\text { Amount }\end{array}$} & \multicolumn{2}{|c|}{$\begin{array}{c}\text { Late } \\
\text { Majority } \\
\text { Amount }\end{array}$} & \multicolumn{2}{|c|}{$\begin{array}{c}\text { Late } \\
\text { Adopters } \\
\text { Amount }\end{array}$} & \multicolumn{2}{|c|}{$\begin{array}{l}\text { Lagards } \\
\text { Amount }\end{array}$} & \multicolumn{2}{|c|}{$\begin{array}{l}\text { Pooled } \\
\text { Amount }\end{array}$} \\
\hline $\begin{array}{l}\text { Revenue } \\
\text { (Naira) }\end{array}$ & USD & $\%$ & USD & $\%$ & USD & $\%$ & USD & $\%$ & USD & $\%$ & USD & $\%$ \\
\hline Sardines: & 378.3 & 44.5 & 338.4 & 42.8 & 202.0 & 25.7 & 105.7 & 17.5 & 98.46 & 14.4 & 224.5 & 30.3 \\
\hline $\begin{array}{l}\text { Sardinella } \\
\text { maderenis }\end{array}$ & 7 & & 1 & & 1 & & 0 & & & & 9 & \\
\hline Brackish & 06.8 & 12.6 & 113.7 & 14.4 & 218.5 & 27.8 & 205.1 & 34.0 & 326.1 & 47.7 & 194.0 & 26.2 \\
\hline $\begin{array}{c}\text { Catfish: } \\
\text { Chrysichthys } \\
\text { nigrodigitatus }\end{array}$ & 1 & & 7 & & 3 & & 0 & & 9 & & 8 & \\
\hline Sharks: & 332.0 & 39.1 & 322.5 & 40.9 & 312.5 & 39.7 & 124.7 & 20.7 & 158.1 & 23.2 & 250.0 & 33.7 \\
\hline $\begin{array}{c}\text { Etamopterus } \\
\text { penyi }\end{array}$ & 8 & & 8 & & 8 & & 8 & & 8 & & 4 & \\
\hline Shrimps: & 417.6 & 49.2 & 371.7 & 47.1 & 380.7 & 48.4 & 269.0 & 44.6 & 289.7 & 42.4 & 345.7 & 46.6 \\
\hline $\begin{array}{c}\text { Nematopalaem } \\
\text { on hastatis }\end{array}$ & 4 & & 9 & & 0 & & 2 & & 1 & & 7 & \\
\hline A. $\frac{\frac{\text { Total }}{\text { Reven }}}{\underline{\text { ue }}}$ & $\begin{array}{c}1234 . \\
90\end{array}$ & & $\begin{array}{c}1146 . \\
55\end{array}$ & & $\begin{array}{c}1113 . \\
82\end{array}$ & & $\begin{array}{c}704 . \\
60\end{array}$ & & $\begin{array}{c}872 . \\
54\end{array}$ & & $\begin{array}{c}1014 . \\
47\end{array}$ & \\
\hline $\begin{array}{c}\text { Labour } \\
\text { (manday) }\end{array}$ & $\begin{array}{c}222.2 \\
0\end{array}$ & 26.2 & $\begin{array}{c}221.7 \\
3\end{array}$ & 28.1 & $\begin{array}{c}203.2 \\
1\end{array}$ & 25.9 & $\begin{array}{c}191.9 \\
7\end{array}$ & 31.7 & $\begin{array}{c}146.5 \\
4\end{array}$ & 21.4 & $\begin{array}{c}197.1 \\
3\end{array}$ & 26.5 \\
\hline $\begin{array}{c}\text { Bait } \\
\text { (Kilogramme) }\end{array}$ & 26.30 & 3.1 & 33.77 & 4.3 & 22.79 & 2.9 & 26.77 & 4.4 & 19.97 & 2.9 & 25.92 & 3.5 \\
\hline Fuel (liters) & $\begin{array}{c}150.1 \\
6\end{array}$ & 17.7 & $\begin{array}{c}138.1 \\
8\end{array}$ & 17.5 & $\begin{array}{c}151.4 \\
8\end{array}$ & 19.3 & 53.61 & 8.9 & $\begin{array}{c}120.1 \\
2\end{array}$ & 17.6 & $\begin{array}{c}122.7 \\
1\end{array}$ & 16.5 \\
\hline $\begin{array}{l}\text { Lubricants } \\
\text { (liters) }\end{array}$ & $\begin{array}{c}155.0 \\
0\end{array}$ & 18.2 & $\begin{array}{c}128.3 \\
2\end{array}$ & 16.3 & $\begin{array}{c}150.0 \\
9\end{array}$ & 19.1 & 85.19 & 14.1 & $\begin{array}{c}132.4 \\
5\end{array}$ & 19.4 & $\begin{array}{c}130.2 \\
1\end{array}$ & 17.5 \\
\hline $\begin{array}{l}\text { Charge on } \\
\text { Gross Vessel } \\
\text { Length (Naira) }\end{array}$ & 17.03 & 2.0 & 20.01 & 2.5 & 15.00 & 1.9 & 12.08 & 2.0 & 12.08 & 1.8 & 15.24 & 2.1 \\
\hline $\begin{array}{l}\text { Water Penalty } \\
\text { (Naira) }\end{array}$ & 16.70 & 1.9 & 13.00 & 1.6 & 7.10 & 0.9 & 7.00 & 1.2 & 5.00 & 0.7 & 9.75 & 1.3 \\
\hline B. $\frac{\text { Total }}{\underline{\text { Variab }}} \underline{\underline{\text { le Cost }}}$ & $\begin{array}{c}587.3 \\
9\end{array}$ & 69.2 & $\begin{array}{c}555.0 \\
1\end{array}$ & 70.3 & $\begin{array}{c}549.6 \\
7\end{array}$ & 69.9 & $\begin{array}{c}376 . \\
62\end{array}$ & 62.5 & $\begin{array}{c}436 . \\
16\end{array}$ & 63.8 & $\begin{array}{c}500.9 \\
6\end{array}$ & 67.5 \\
\hline $\begin{array}{l}\text { Depreciation } \\
\text { (Naira) }\end{array}$ & $\begin{array}{c}140.0 \\
0\end{array}$ & 16.5 & $\begin{array}{c}148.0 \\
0\end{array}$ & 18.7 & $\begin{array}{c}160.0 \\
3\end{array}$ & 20.4 & $\begin{array}{c}171.0 \\
0\end{array}$ & 28.3 & $\begin{array}{c}187.9 \\
7\end{array}$ & 27.5 & $\begin{array}{c}161.4 \\
0\end{array}$ & 21.7 \\
\hline $\begin{array}{c}\text { Registration } \\
\text { and Training } \\
\text { (Naira) }\end{array}$ & $\begin{array}{c}102.0 \\
0\end{array}$ & 12.0 & 70.00 & 8.9 & 60.00 & 7.6 & 38.55 & 6.4 & 42.80 & 6.3 & 62.67 & 8.4 \\
\hline Dues (Naira) & 20.00 & 2.3 & 16.35 & 2.1 & 16.35 & 2.1 & 16.35 & 2.7 & 16.35 & 2.4 & 17.08 & 2.3 \\
\hline C. $\frac{\text { Total }}{\underline{\text { Fixed }}}$ & $\begin{array}{c}262.0 \\
0\end{array}$ & 30.8 & $\begin{array}{c}234.3 \\
5\end{array}$ & 29.7 & $\begin{array}{c}236.3 \\
8\end{array}$ & 30.1 & $\begin{array}{c}225 . \\
90\end{array}$ & $\begin{array}{c}37.4 \\
9\end{array}$ & $\begin{array}{c}247 . \\
12\end{array}$ & 36.2 & $\begin{array}{c}241.1 \\
5\end{array}$ & 32.5 \\
\hline $\begin{array}{l}\text { D. Total } \\
\text { Cost in } \\
\text { Naira } \\
(B+C)\end{array}$ & $\begin{array}{c}849.3 \\
9\end{array}$ & $\begin{array}{c}100 . \\
0\end{array}$ & $\begin{array}{c}789.3 \\
6\end{array}$ & $\begin{array}{c}100 . \\
0\end{array}$ & $\begin{array}{c}786.0 \\
5\end{array}$ & $\begin{array}{c}100 . \\
0\end{array}$ & $\begin{array}{c}602 . \\
52\end{array}$ & $\begin{array}{c}100 . \\
0\end{array}$ & $\begin{array}{c}683 . \\
28\end{array}$ & $\begin{array}{c}100 . \\
0\end{array}$ & $\begin{array}{c}742.1 \\
1\end{array}$ & $\begin{array}{c}100 . \\
0\end{array}$ \\
\hline $\begin{array}{ll}\text { E. } & \text { Gross } \\
\text { Margi } \\
n \text { in } \\
\text { Naira } \\
\{A-B\}\end{array}$ & $\begin{array}{c}647.5 \\
1\end{array}$ & 76.2 & $\begin{array}{c}591.5 \\
4\end{array}$ & 74.9 & $\begin{array}{c}564.1 \\
5\end{array}$ & 71.8 & $\begin{array}{c}327 . \\
98\end{array}$ & $\mathbf{5 4 . 4}$ & $\begin{array}{c}436 . \\
38\end{array}$ & 63.8 & $\begin{array}{c}513.5 \\
0\end{array}$ & 69.2 \\
\hline F. Net & 385.5 & 45.4 & 357.1 & 45.3 & 327.7 & 41.7 & 102. & 16.9 & 189. & 27.7 & 272.3 & 36.7 \\
\hline
\end{tabular}




\begin{tabular}{|c|c|c|c|c|c|c|c|}
\hline & $\begin{array}{l}\text { Incom } \\
\text { e in } \\
\text { Naira } \\
\{A- \\
(B+C)\}\end{array}$ & 1 & 9 & 7 & 08 & 26 & 5 \\
\hline G. & $\begin{array}{l}\text { RTI } \\
\{100(F \\
\text { /D)\} } \\
\text { (Perce } \\
\text { ntage) }\end{array}$ & 45.4 & 45.3 & 41.7 & 16.9 & 27.7 & 36.7 \\
\hline H. & $\begin{array}{l}\text { Benefi } \\
\text { t Cost } \\
\text { Ratio }\end{array}$ & 1.454 & 1.453 & 1.417 & 1.169 & 1.277 & 1.367 \\
\hline
\end{tabular}

Source: Field Survey 2013

\section{Reference}

Abiodun, A. (1994). 'Fishermen Job perception and Mobility: A study in Socio-Economic and Fishery Management'. An unpublished Ph.D. Thesis in Department of Agricultural Economics, University of Aberdeen.

Adedeji, O. H., L. Ibeh and F. F. Oyebanji (2011). Sustainable Management of Mangrove Coastal Environments in the Niger Delta Region of Nigeria: Role of Remote Sensing and GIS Proceedings of the Environmental Management Conference, Federal University of Agriculture, Abeokuta, Nigeria. Pp. 308-326

Adeyemo, O.K. (2003) Consequences of Pollution and Degredation of Nigerian Aquatic Environment on Fisheries Resources. Environmentalist, Vol 23: 4 Pp 297-306.

Bisong, F.E. (2001). Natural Resource Use and Conservation Systems for Sustainable Rural Development. Calabar, (Ed). Baaj International.

Cameron, L. A. (1999). The Importance of Learning in the Adoption of High-Yielding Variety seeds. American Journal of Agricultural Economics. 81. 83-94

Eayrs, S (2005). A Guide to By-catch Reduction in Tropical hrips-Trawl Fisheries Food and agricultural Organization Rome, Italy.

Eboh, E.C. (1995). Sustainable development: the theory and implications for rural Nigeria. In rural development in Nigeria: concepts, processes and prospects. Eboh et al (eds), Autocentury publishing company limited, Enugu, Nigeria pp.3-12

Ehirim, N.C., Okunmadewa F.Y., Rahji M.A.Y., Awoyemi T.T., Oyekale A.S., Salman, K.K and Yusuf, S.A. (2013). Determinants of Adoption Intensity of EnvironmentalSustainable Fishing Techniques by artisanal Fishermen in Akwa Ibom State Nigeria. International Journal of Agriculture and Rural Develoment. Volume 16 (1):1354-1367

Hussen, A. M. (2004). Principle of Environmental Economics Routledge 29 West 35th Street, New York, NY 10001 Second Edition Pp 32-80

Ita, E.O (1992). Inland Fishery Resource of Nigeria. CIFA Occassional Papper No. 20 CIFA/OP20. National Institute for Freshwater Fisheries Research, New Bussa, Niger State, Nigeria.

James, G. K. (2008). Assessment of Environmental Change and Its Socio-economic Impacts in the Mangrove Ecological Zone of the Niger Delta, Nigeria. Unpublished Thesis, University of Missouri

James, G. K., J. O. Adegoke, E. Saba, P. Nwilo and J. Akinyede (2007). Satellite-Based Assessment of the Extent and Changes in the Mangrove Ecosystem of the Niger Delta. Marine Geodesy, 30, 249 - 267

Lionberger, H.F. (1960). Adoption of New Ideas and Practice. Iowa State: University Press. In Lowenberg-DeBoer, J. "Comment on Site-Specific Crop Management Adoption Pattern and incentives." Review of Agricultural Economics 40 12-19

Mmom, P. C. and Arokoyu, S. B. (2010). Mangrove Forest Depletion, Biodiversity Loss and Traditional Resources Management Practices in the Niger Delta, Nigeria Research Journal of Applied Sciences, Engineering and Technology, Maxwell Scientific Organization. Vol. 2(1): 28-34, ISSN: 2040-7467.

Mmom, P.C., (2007). Impact of Human Density and Economic Activities on the Mangrove forest of the Niger Delta, Nigeria. Paper presented at the Annual Conference of the International Association for Impact Assessment, held in Seoul South Korea. 1-9 June.

Naylor, R. L., K. M. Bonine, K. C. Ewel, and E. Waguk (2001). Migration, Markets, and Mangrove Resource Use on 
Kosrae, Federated States of Micronesia MacArthur PCE Draft,

NDDC (2004). The Niger Delta Master Plan report for Agriculture and Fishery sub-sector. Niger Delta Development Office, Port Harcourt River State Nigeria

Oko, M. and L. Zelin (2010). Reefs and Mangroves Essential for Economic Growth in Dominican Republic. A Working Paper on Mangrove Development. World Research Institute USA

Olanike K. A., O. E. Ubiogoro and O. B. Adedeji (2009). Oil Exploitation, Fishery Resources and Sustainable Livelihood in the Niger Delta Region, Nigeria. in Nature and Fauna Food and Agricultural Organization of Nigeria Regional office for Africa. Vol 24 Issue 1

Ozor, N and M.C. Madukwe (2001). Adoption of Improved rabbit Technology in Nsukka Local Government Area of Nigeria. Implication for Live stock Extension. "in" Proceeding of the $6^{\text {th }}$ Annual Conference of Animal Science Association of Nigeria. University of Maidugri Pp.199-202

World Bank (1995) Defining Environment Strategy for the Niger Delta. World Development Report. ISBN 0-19521102-2 